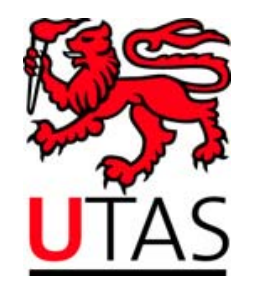

SCHOOL OF ECONOMICS AND FINANCE

Discussion Paper 2013-08

\title{
Commodity Prices and BRIC and G3 Liquidity: A SFAVEC Approach
}

Ronald A Ratti and Joaquin L Vespignani

ISBN 978-1-86295-914-9 


\title{
Commodity Prices and BRIC and G3 Liquidity: A SFAVEC Approach
}

\author{
Ronald A. Ratti ${ }^{\mathrm{a}^{*}}$ and Joaquin L. Vespignani $\mathrm{i}^{\text {***}}$ \\ ${ }^{a}$ University of Western Sydney, School of Business, Australia \\ ${ }^{b}$ University of Tasmania, School of Economics and Finance, Australia
}

\begin{abstract}
This paper investigates the influence of liquidity in the major developed and major developing economies on commodity prices. Unanticipated increases in the BRIC countries' liquidity is associated with significant and persistent increases in commodity prices that are much larger than the effect of unanticipated increases in G3 liquidity, and the difference increases over time. Over 1999-2012 BRIC liquidity is strongly linked with global energy prices and global real activity whereas G3 liquidity is not. The impact of BRIC liquidity on mineral and metal prices is twice as large as that of G3 liquidity. BRIC liquidity is significantly connected with global tightening while G3 liquidity is not. Granger casualty goes from liquidity to commodity prices. BRIC and G3 liquidity and commodity prices are cointegrated. BRIC and G3 liquidity and global output and global prices are cointegrated. We constructed a structural factor-augmented error correction (SFAVEC) model.
\end{abstract}

Keywords: Commodity Prices, BRIC countries, G3, Global liquidity, SFAVEC

JEL Codes: E31, E32, E51, F01, G15, Q43

*Ronald A. Ratti; University of Western Sydney, School of Business, Australia; Tel. No: +61 29685 9346; Email address: r.ratti@uws.edu.au

*** Corresponding author: Joaquin L. Vespignani; University of Tasmania, School of Economics and Finance, Australia; Tel. No: +61 3 62262825; E-mail address: Joaquin.Vespignani@utas.edu.au 


\section{Commodity Prices and BRIC and G3 Liquidity: A SFAVEC Approach}

\section{Introduction}

The effect of global liquidity on the prices of commodities, goods and assets has been a focus of recent research. Sousa and Zaghini (2007) find that global excess liquidity signals inflationary pressure at a global level. D'Agostino and Surico (2009) demonstrate that global liquidity has predictive power for the US inflation rate. Darius and Radde (2010) show that global liquidity has impact on a commodity price index (but not on equity prices and oil prices). Belke et al. (2010) document that the dramatic increase in global liquidity since 2001 has had impacts on the price of assets in inelastic supply including commodities. Anzuini et al. (2012) find that US monetary expansion has a significant, but modest effect on commodity prices. Ratti and Vespignani (2013) report that increases in global liquidity have had a positive effect on oil prices in recent years. Theoretically increases in liquidity are likely to be associated with a rise in aggregate demand and this will increase the price of most assets including commodity prices. ${ }^{1}$

In this paper we seek to determine the influence of liquidity as it arises from the major developed and major developing economies on commodity prices. Hamilton (2013) notes that the newly industrialized economies have absorbed over two-thirds of the increase in world oil consumption since 1998. Kilian and Hicks (2013) associate the rise in real oil price over 2003-2008 with growth in emerging economies, primarily that in China and India. Radetzki (2006) surmises that in developing Asian countries a dollar added to the GDP uses more than twice the quantity of commodities as does a dollar added to the GDP in OECD countries and notes that between 2000 and 2005, just China's share of global demand growth for petroleum was $28 \%$, for aluminium was more than $50 \%$, for steel was more than $84 \%$, and for copper

\footnotetext{
${ }^{1}$ Barsky and Kilian (2004) maintain that monetary policy influences commodity prices through expectations of greater growth and inflation. Frankel and Hardouvelis (1985) argue that movement in commodities prices measure the market's assessment of the stance of monetary policy. Frankel (1984) notes that increase in money will raise the real price of commodities because the prices of many other goods are inflexible in the short.
} 
was 95\%. Humphreys (2010) notes that industrialization increases demand for metals substantially and that development in the BRIC economies is a major factor in the boom in metal prices from 2003 to 2008. Roberts and Rush (2010) argue that commodity resources are used intensively in traded goods and that this is a part of the demand for commodities by rapidly developing countries. Dungey et al. (2013) find that shocks to Chinese demand result in sustained increase in commodity prices in the Australian mining sector.

In this paper the major developing economies are taken to be the BRIC countries (Brazil, the Russian Federation, India and China). The major developed economies are taken to be the G3, the world's three leading economic blocs - the US, Japan and the European Union (EU). The BRIC countries have become much more important providers of global liquidity in recent years. Information on M2 in US dollars for the BRIC countries and for the G3 over 1999:01-2011:12 is provided in Figure 1. The scale of the right hand side of Figure 1 is for M2 for the BRIC countries and the scale of the left hand side of Figure 1 is for M2 for the G3. Over the fourteen years from 1999:01 to 2012:12 M2 is up approximately by a factor of 13.3 in BRIC countries. In contrast, over 1999:01 to 2012:12, M2 is up by a factor of 2.4 in the G3. BRIC M2 goes from being only about $10 \%$ of G3 M2 at the start of the period to being over $50 \%$ by the end of the period. Our view is that it greatly matters in assessing the impact of liquidity on commodity prices as to where the innovation in liquidity is originating.

The logs of US dollar commodity price index and commodity price component indices for energy commodities, agriculture commodities, mineral and metal commodities, precious metal commodities, and raw materials commodities are shown in Figure 2. The underlying indices are set at 100 for 2005. From 1999:01 to 2012:12 the commodity price index is up by a multiple of 3.71. Over the same period energy prices, agriculture prices, mineral and metal prices, precious metal prices, and raw materials prices have increased by multiples of about 4.22, 3.19, 3.60, 4.01, and 3.19, respectively. 
A structural factor augmented vector error correction (SFAVEC) model is employed in the analysis of the effect of innovations in BRIC liquidity and G3 liquidity on global commodity prices. $^{2}$ A factor augmented dimension to the SVEC model will capture the dynamic of the information provided by many variables to the analysis of short and long run influence of liquidity on global commodity prices, global industrial production, global inflation and global interest rate. Granger casualty goes from liquidity to commodity prices. BRIC M2 and G3 M2 are cointegrated with commodity prices and with global inflation and global output.

It is found that positive innovations in BRIC liquidity are linked with much larger positive effects on commodity prices than are positive shocks in G3 liquidity. The disparity in the effect of BRIC liquidity compared G3 liquidity on commodity prices grows over time. Positive shocks in BRIC liquidity have much larger effects on energy prices, mineral and metal prices, and raw material prices than do positive shocks in G3 liquidity. Shocks to G3 liquidity have larger effects than shocks to BRIC liquidity on precious metal prices. A positive shock in BRIC M2 is associated with significant increases in global industrial production and global interest rates whereas shocks to G3 liquidity are not. Results are robust to alternative identification schemes in the structural FAVAR, to different measurement of global variables, to treatment of the global financial crisis, and to variation in lag length.

The data, variables and cointegration are discussed in Section 2. The structural vector error correction (SFAVEC) model for analysis of liquidity and real crude oil prices is introduced in Section 3. The empirical results are presented in Section 4. Robustness of results is investigated in Section 5. Section 6 concludes.

\footnotetext{
${ }^{2}$ The literature on the identification of monetary policy in a VAR framework is expanding in several directions. Bernanke et al. (2005) propose a Factor Augmented VAR (FAVAR) to identify monetary policy shocks. A small number of factors (principal components ) can summarize large amounts of information about an economy and be included in the FAVAR. Dees et al. (2007) propose a global VAR (GVAR). The GVAR combines separate models for each of the many economies linking core variables within each economy with foreign variables using quarterly data. The foreign variables external to a domestic economy are trade-weighted.
} 


\section{Data, Variables and Cointegration}

In this paper we will construct a structural factor-augmented error correction (SFAVEC) model to estimate the impacts of increases in BRIC and in G3 liquidity on global commodity prices. Given that the model will incorporate principal component variables, cointegration vectors and ordering restrictions it is convenient to discuss the data, variables and cointegration vectors in this section before discussing the SFAVEC model.

\subsection{The data}

The model is constructed with monthly data from January 1999 to December 2012. The starting period is dictated by the creation of the European central bank, the availability of Eurozone interest rate data, and the availability of data at monthly frequency for the BRIC countries. It is necessary to use monthly data since the sample period is unavoidably comparatively short.

The monetary aggregate indicators are M2 for the G3 economies ( $\left.G 3 M 2_{t}\right)$, US, Japan and the EU (taken to be the Eurozone and UK), and M2 for the BRIC economies $\left(B R I C M 2_{t}\right)$, Brazil, Russia, India and China. The monetary aggregates are measured in US dollars. Global commodity prices $\left(\mathrm{COM}_{t}\right)$, overall, energy, non-energy, mineral and metal, precious metal, and raw materials prices are in US dollars. We will also construct a global interest rate $\left(G I R_{t}\right)$ variable, a global inflation rate $\left(G C P I_{t}\right)$ variable, and a global industrial production $\left(G I P_{t}\right)$ variable based the on the interest rate, industrial production and CPI inflation in each of the BRIC and G3 economies. The global commodity price data and commodity price component data are from World Bank and the International Monetary Fund. The M2 data for US, Eurozone, UK, Japan, Brazil and Russian Federation is from International Monetary Fund and the Federal Reserve Bank of St. Louis, while China's and 
India's M2 are from People's Bank of China and Reserve Bank of India, respectively. ${ }^{3}$ The exchange rate data to convert M2 series from domestic currency into US dollars is obtained from Federal Reserve Bank of St. Louis. ${ }^{4}$ All other variables are from the Federal Reserve Bank of St. Louis (FRED data).

\subsection{Global interest rate, inflation rate and industrial production}

We construct global indicators of the interest rate, inflation rate and industrial production. These variables for each of the BRIC and G3 economies clearly play a role in the link between global liquidity and commodity prices. A problem is to find a practical way to compress the information on interest rates, inflation and economic activity in each of the G3 and BRIC economies into a few variables. In this section we will construct global indicators of the interest rate, inflation rate and industrial production based on principal components methodology applied to data for the G3 and BRIC economies. In robustness tests of the results in the paper we will use an alternative method to obtain global indicators of these variables by using nominal GDP weights converted to a single currency (interpolated monthly) applied to the appropriate variable for each individual economy.

Bernanke et al. (2005) proposed a factor-augmented vector autoregressive model (FAVAR) based on the development of principal components analysis outlined by Stock and Watson (2002). One of the main advantages of this methodology is that a single individual variable or factor can capture the dynamic of a large amount of information contained in many variables. Facing a large number of variables included in this study, we use principal component indexes as indicators capturing the effects of global interest rates, global industrial production and global inflation by compressing in turn local information on these

\footnotetext{
${ }^{3}$ Note for India the monetary aggregates L2 has been used as a proxy of M2, as the Reserve Bank of India does not report monthly M2 aggregates for this period.

${ }^{4}$ Russian federation exchange rate has been interpolated from the annual series as monthly data for Ruble /US dollars is not available for the full sample period.
} 
variables in the BRIC and G3 economies. The BRIC and G3 economies account for over $75 \%$ of global GDP measured by purchase power parity for the full data period. The indicators of global interest rate, global industrial production and of global inflation are the leading principal components of the BRIC and G3 economies' interest rates, industrial production and inflation (in log-level form for industrial production and CPI inflation):

$$
\begin{aligned}
& G I R_{t}=\left[I R_{t}^{E A}, I R_{t}^{U S}, I R_{t}^{C H}, I R_{t}^{J a}, I R_{t}^{U K}, I R_{t}^{I n}, I R_{t}^{R u}, I R_{t}^{B r}\right] \\
& G I P_{t}=\left[I P_{t}^{E A}, I P_{t}^{U S}, I P_{t}^{C H}, I P_{t}^{J a}, I P_{t}^{U K}, I P_{t}^{I n}, I P_{t}^{R u}, I P_{t}^{B r}\right] \\
& G C P I_{t}=\left[C P I_{t}^{E A}, C P I_{t}^{U S}, C P I_{t}^{C H}, C P I_{t}^{J a}, C P I_{t}^{U K}, C P I_{t}^{I n}, C P I_{t}^{R u}, C P I_{t}^{B r}\right]
\end{aligned}
$$

In equation (1), GIR $R_{t}$ is a vector containing the discount rate of the central banks of the Euro area, UK, US, China, Japan, India, Russia and Brazil. Equations (2) and (3) are vectors containing the industrial production and inflation for the same countries, respectively. ${ }^{5}$

The first principal component for the global interest rate, which to economize on notation we will refer to as $G I R_{t}$, is drawn in Figure 3a. It captures the collapse in interest rates at the end of 2008 with the onset of the global financial crisis as well as the relatively low interest rates over the period 2002 to 2006. The first principal component for the CPI indices, $G C P I_{t}$, is shown in Figure $3 \mathrm{~b}$. In Figure $3 G C P I_{t}$ slopes linearly upward. This indicates an overall flat rate of inflation, consistent with low and moderate inflation in the BRIC and G3 economies over 1999-2012 (the basic data are logs of CPI levels). There are brief periods when inflation seems to flatten out or speed up in line with weaknesses in the global economy and movement in commodity prices.

The first principal component for global industrial production, $G I P_{t}$, is represented in Figure 3c. Global industrial production has an upward trend until the global financial crisis in 2008. There is a severe correction in $G I P_{t}$ in 2008-2009, reflecting the global financial crisis, with recovery of global industrial production to early 2008 levels only in 2011. Global

\footnotetext{
${ }^{5}$ Discussion of the principal component estimation is presented in Appendix A.
} 
industrial production also shows a correction in 2001 coinciding with the March-November 2001 recession in the US.

Information on the correlations between country-specific and global factor for the short-term interest rate (IR), for industrial production (IP), and for the inflation rate (CPI) in turn are reported in the columns in Table 1. The global factors are given by first principal components for the global interest rate (GIR), global industrial production rate (GIP), and global inflation rate (GCPI). The global interest rate correlation with country interest rates is high for most countries and low for India and Brazil (with correlation coefficients of 0.32 and 0.38 , respectively). The global industrial production correlation with country industrial production is high for each of the BRIC countries (at 0.92 and above), at 0.61 or 0.62 for the Euro area and the US, and low for Japan (at 0.31) and the UK (-0.62). The global CPI correlation is high with all economies CPI's at 0.95 and above, except for the correlation with Japan's CPI.

\subsection{Causality test}

In Tables 2 and 3 the Granger causality direction between G3 M2 and commodity prices and between BRIC M2 and commodity prices are reported. The null hypothesis that commodity prices do not Granger cause BRIC M2 and the null hypothesis that commodity prices do not Granger cause G3 M2 cannot be rejected at conventional levels (using most lags structures). These results hold when the test is performed in log-level and in log-difference form.

The null hypothesis of BRIC M2 does not Granger causes commodity prices is rejected to $1 \%$ level using both log-level and log-difference form, confirming that causal direction is from BRIC M2 to commodity prices. Results for the G3 M2 and commodity prices are less clear. The null hypothesis that G3 M2 does not granger cause commodity 
prices is rejected for variables in log-level form but is not rejected in difference-level form. Overall, we conclude that Granger casualty goes from liquidity to commodity prices.

\subsection{Stationarity and Cointegration test}

In table 4 the stationary properties of the data are reported. For this purpose both the Augmented Dickey-Fuller (ADF) test and the Kwiatkowski-Phillips-Schmidt-Shin (KPSS) are estimated for all variables. ${ }^{6}$ Results show that variables are only first difference stationary. In empirical estimation the interest rate is used in levels in line with most macroeconomics studies.

We now examine possible cointegration among the price, monetary aggregate and output variables in the model. This is in keeping with the quantity theory of money as noted by and in empirical studies by Swanson (1998), Bachmeier and Swanson (2005), Garret et al. (2009) and others. The long-run relationship between global liquidity and commodity prices has been also well established in the literature. ${ }^{7}$ Here we are interested in cointegration results for two relationships, that for BRIC M2, G3 M2 and global commodity prices, and that for BRIC M2, G3 M2, and global activity and global (consumer) prices. To formally establish the cointegration relationship among these variables, we use the Johansen's cointegration test. $^{8}$

Table 5 reports results for the Johansson cointegration tests. In Table 5.1, results reveal that $\log$ of commodity prices, BRIC M2 and G3 M2 are a cointegrated vector when the test is specified with intercept. In table 5.2, the test for cointegration among global inflation, global output and G3 M2 and BRIC M2 shows one cointegration vector when both intercept and linear trend are introduced to the model. Consequently two cointegration vectors are introduced into the model and are specified as follows:

\footnotetext{
${ }^{6}$ Note that the appeal of using both methods is that they have inverse hypothesis. The null hypothesis for the $\mathrm{ADF}$ test is the variable has a unit root and the null hypothesis for the KPSS test is that the variable is stationary, this improve the robustness of the results.

${ }^{7}$ See for example Darius and Raddle (2010) and Belke et al. (2013).

${ }^{8}$ For more detail of this test please see Enders (2004), pp. 362.
} 


$$
\begin{gathered}
E C T 1_{t}=\log \left(C O M_{t}\right)-\beta-\mu \log \left(B R I C M 2_{t}\right)-\sigma \log \left(G 3 M 2_{t}\right) \sim I(0) \\
E C T 2_{t}=\log \left(G C P I_{t}\right)-\beta-\gamma \log \left(G I P_{t}\right)-\pi \log \left(B R I C M 2_{t}\right)-\varphi \log \left(G 3 M 2_{t}\right)-\theta t \sim I(0)
\end{gathered}
$$

\section{The model}

Following Bernanke et al.'s (2005) idea of incorporating principal component vectors in a simultaneous equation model, we construct a structural factor-augmented error correction (SFAVEC) model with the following variables: $G I R_{t}, G 3 M 2_{t}, B R I C M 2_{t}, G C P I_{t}, G I P_{t}$ and $\mathrm{COM}_{t}$ and two error correction terms specified in equations 4 and $5 .^{9}$

The SFAVEC model can expressed as:

$$
B_{0} X_{t}=\beta+\sum_{i=1}^{j} B_{i} X_{t-i}+\omega E C T 1_{t-1}+\rho E C T 2_{1}+\varepsilon_{t}
$$

where $j$ is optimal lag length, determined by the Schwarz criterion (one lag in this case), $X_{t}$ is vector of endogenous variables, $E C T_{t}$ is the error correction term, and $\varepsilon_{t}$ is the vector of structural changes, which is serially and mutually independent.

The vector $X_{t}$ is expressed as:

$X_{t}=\left[G I R_{t}, \Delta \log \left(G 3 M 2_{t}\right), \Delta \log \left(B R I C M 2_{t}\right), \Delta \log \left(G C P I_{t}\right), \Delta \log \left(G I P_{t}\right), \Delta \log \left(C O M_{t}\right)\right](7)$

In line with Bernanke (1986), Sims and Zha (1995), Kim and Roubini (2000) and Kim (2001) non-recursive identify restrictions are proposed in the contemporaneous structure. The $B_{0} X_{t}$ identification restrictions are:

$$
B_{o} X_{t}=\left[\begin{array}{cccccc}
1 & -b_{01} & -b_{02} & 0 & 0 & 0 \\
-b_{10} & 1 & 0 & -b_{13} & -b_{14} & 0 \\
-b_{20} & -b_{21} & 1 & -b_{23} & -b_{24} & 0 \\
0 & 0 & 0 & 1 & -b_{34} & 0 \\
0 & 0 & 0 & 0 & 1 & 0 \\
0 & 0 & 0 & 0 & 0 & 1
\end{array}\right]\left[\begin{array}{c}
G I R_{t} \\
\Delta \log \left(G 3 M 2_{t}\right), \\
\Delta \log \left(B R I C M 2_{t}\right) \\
\Delta \log \left(G C P I_{t}\right) \\
\Delta \log \left(G I P_{t}\right), \\
\Delta \log \left(C O M_{t}\right)
\end{array}\right]
$$

\footnotetext{
${ }^{9}$ The FAVAR approach in Bernanke et al. (2005) uses a two-step procedure. Factors are estimated by principal components before estimation of the factor-augmented VAR. The number of unobservable factors used for policy analysis may be selected on statistical grounds. We use one factor for global interest rate, global industrial production and global inflation to retain parsimony in the factor augmented VEC approach.
} 
Consistent with Sims and Zha (1995)'s dynamic stochastic general equilibrium model, the monetary policy feedback rule is based on the recognition of information delays that do not allow the monetary policy to respond within the month to price level and output events. The monetary policy rule only responds contemporaneously to G3 and BRIC M2.

Following the literature, the M2 monetary aggregates respond contemporaneously to the domestic interest rate, inflation and industrial production implying that real demand for money depends on the interest rate and real income. Restrictions in both the inflation and output equations (four and fifth equations respectively) are standard in the economic literature assuming that oil or commodity prices affect these variables in the same period on the ground that most commodities (e.g. oil and gas) are crucial inputs for many sectors. ${ }^{10}$

Finally, in the last equation Kim and Roubini (2000) used oil prices as contemporaneously exogenous to all variables in the model due to information delay. However, Anzuini et al. (2012) treats commodity prices as contemporaneously endogenous of all variables in the US economy. The log likelihood ratio test for over-identification restrictions support restrictions in favour of commodity prices to be contemporaneously exogenous as in equation (8). ${ }^{11}$ The robustness of results will be examined to making commodity prices contemporaneously endogenous to all the global variables and liquidity variables.

\section{The empirical results}

\subsection{Impulse responses of global variables to BRIC M2 and G3 M2}

Figures 4 and 5 show the responses of the variables in the SFAVEC model in equations (6)-(8) to one standard deviation generalised impulse response function in BRIC

\footnotetext{
${ }^{10}$ These restrictions have been used by Gordon and Leeper (1994), Sims and Zha (2006), Christiano et al. (1999) and Kim (2001).

${ }^{11}$ The chi square coefficient is 39 when the commodity prices are assumed to be contemporaneously exogenous while this coefficient is 0.4 when these zero restrictions are not imposed.
} 
M2 and in G3 M2. ${ }^{12}$ We are using one standard deviation generalised impulse response function following Pesaran and Shin (1997). ${ }^{13}$ The dashed lines represent a one standard error confidence band around the estimates of the coefficients of the impulse response functions. ${ }^{14}$ It is found that positive innovations in the BRIC countries' liquidity lead to significant and persistent increases in global interest rates, global industrial production and commodity prices. The rise in commodity prices is sharp in the first three months following the BRIC M2 shock and then gradually continues to increase. Following the BRIC M2 shock, most of the rise in global industrial production occurs in the first four months whereas the global interest rate continues to rise as time goes on. The positive shock in BRIC M2 is associated with a boom in global industrial production and global tightening in monetary policy as indicated by increases in central bank discount rates. Innovations in the BRIC countries' liquidity do not significantly affect global inflation. A positive shock in BRIC M2 is associated with positive increase in G3 M2.

In Figure 5 shocks to the G3 economies' liquidity are not associated with statistically significant changes in global interest rates, global inflation, global industrial production, or BRIC M2. A positive innovation in G3 M2 does lead to an increase in commodity prices that is statistically significant for ten months. However, positive innovations in BRIC M2 are linked with a positive effect on commodity prices that is three times as large as the effect of unanticipated increases in G3 liquidity on commodity prices after three months. The magnitude of this relatively larger effect of BRIC M2 compared to G3 M2 on commodity prices then slowly grows over time. The one standard deviation generalised impulse response

\footnotetext{
${ }^{12}$ One standard deviation in BRIC M2 is 0.012 and one standard deviation in G3 M2 is 0.015 . If the impulses were normalized, this would reduce the apparent impact of shocks on commodity price of G3 M2 compared to BRIC M2. Thus, the impulse response results reported in this section understate the influence of BRIC M2 compared to G3 M2 somewhat. For purposes of comparison the standard deviation of the overall commodity price variable is 0.046 .

${ }^{13}$ The advantage of this generalized approach is that unlike the "orthogonalized" impulse responses, it is not invariant to the order of vector autoregression (VAR) variables.

${ }^{14}$ The confidence bands are obtained using Monte Carlo integration as described by Sims (1980), where 5000 draws were used from the asymptotic distribution of the VAR coefficient.
} 
functions of the variables in the SFAVEC model in equations (6)-(8) to shocks to all the variables is available as Figure 10 in the Appendix.

\subsection{Cumulative response of commodity prices}

The cumulative contributions to commodity price of the structural shocks to G3 M2 and to BRIC M2 are reported in Figure 6a from estimating the SFAVEC model in equations (6)-(8). The cumulative contributions of structural shocks to commodity price are the moving average of the last 12 months to improve the readability of the plot. Contextual information on the behaviour of commodity prices over 1999-2012 is provided in Figure 2. Commodity prices fell during 2001 with recession in the US and fell sharply at the end of 2008 during the global financial crisis. Commodity prices rose particularly sharply over 2006-2008.

In Figure 3 the rapid increase in commodity price leading to a peak in June 2008 is associated with positive structural shocks to BRIC M2. The fall in commodity price from July 2008 to January 2009 is associated with the global financial crisis during late 2008, recession in the US over December 2007 to June 2009, and weak growth in Europe. Figure 3 suggests that BRIC M2 and G3 M2 did not contribute to this decline in commodity price. The cumulative impact of the BRIC countries' M2 on the commodity price is positive in the recovery of commodity price during 2009 and 2010.

Figure $6 \mathrm{~b}$ shows the difference in the cumulative effect on commodity price of structural shocks to BRIC M2 and G3 M2 (BRIC-G3 M2) over 1999:01-2012:12. A positive (negative) value for BRIC-G3 M2 indicates a larger (smaller) effect of BRICM2 on commodity price than that of G3M2. In Figure $6 \mathrm{~b}$ the contribution to commodity price of liquidity in BRIC countries relative to that of liquidity in G3 countries is much bigger since 2005. The relative contribution of the BRIC countries' liquidity to commodity price is particularly important during 2006 through 2008 and from the end of 2009 through 2010, in line with the rise in the economic importance of the BRIC economies. 


\subsection{Impulse response of commodity price components}

We now examine the response of commodity price components to innovations in BRIC M2 and in G3 M2. In the SFAVEC model in equations (6)-(8) the variable $\Delta \log \left(\mathrm{COM}_{t}\right)$ is replaced by the log difference of a commodity price component index (one at a time). The commodity price component indices considered are for energy commodities, agriculture commodities, mineral and metal commodities, precious metal commodities, and raw materials commodities. The responses of the commodity price component indices innovations in G3 M2 and in BRIC M2 are shown in first column and in the second column, respectively, in Figure 7.

It is found that positive innovations in the BRIC countries' liquidity lead to statistically significant and persistent increases in global energy prices. The rise in energy prices is very steep in the first two months and then energy prices continue to rise. Shocks to G3 liquidity have a small positive effect on global energy prices that is not statistically significant. Positive innovations in both G3 and BRIC liquidity have positive and statistically significant effects on agricultural prices that persist over time. The size of the effects of G3 and BRIC liquidity on agricultural prices are similar in the first few months, with a tendency for the BRIC effect to grow larger over time while the G3 effect does not (after the first four months).

Positive shocks in G3 and BRIC liquidity have positive and statistically significant effects on mineral and metal prices that persist over time. The size of the impact of BRIC M2 on mineral and metal prices is over $60 \%$ larger than that of G3 M2 three months after the shock. The BRIC liquidity effect on mineral and metal prices continues to grow larger over time and after twenty months is over twice the size of the effect of increases in G3 liquidity. Positive innovation in BRIC M2 accompanies statistically significant and growing increase in raw materials prices. Positive shocks to G3 M2 have a positive effect on global raw materials 
prices that is statistically significant over a two to six month window. Increases in both G3 and BRIC liquidity have positive and statistically significant effects on precious metal prices that persist over time. On precious metal prices, the size of the effects of G3 M2 is twice as large as that of the effects of and BRIC M2.

The overall conclusion of this section in that positive shocks in BRIC M2 have much larger effects on commodity prices, energy prices, mineral and metal prices, and raw material prices than do positive shocks in G3 M2. Shocks to G3 liquidity did not have a statistically significant effect on global energy prices. It is only on precious metal prices that shocks to G3 M2 have larger effects than shocks to BRIC M2. The results for the effects of structural innovations in BRIC M2 and in G3 M2 on commodity price component indices is consistent with the result in the previous sub-section that the magnitude of the positive effect of positive BRIC M2 innovations compared to positive G3 M2 innovations on commodity prices is much larger and that the disparity grows over time.

\section{Robustness analysis}

In this section we evaluate the robustness of our model by exploring outcomes when using different indicators for global interest rates, industrial production and inflation, alternative identification restrictions, and lag structures.

\subsection{Global variables: alternative global weights}

In the earlier analysis the influence of global interest rate, global industrial production and global inflation is captured by the leading principal components from interest rates, industrial production and inflation in the BRIC and G3 economies. Beyer et al. (2000), Giese and Tuxen (2007), and Belke et al. (2013) aggregate global variables by using nominal GDP weights converted to a single currency (interpolated monthly). We constructed a global indicator of interest rate, inflation and industrial production by using nominal GDP relative to 
total GDP (G3 and BRIC GDP) weights for the US, Eurozone, UK, Japan, Brazil, Russia, India and China economies. These three global indicators are substitute for $G I R_{t}$, $\Delta \log \left(G C P I_{t}\right)$ and $\Delta \log \left(G I P_{t}\right)$ in equations (5) to (8). The impulse responses are re-estimated from the reconstituted SFAVEC model.

Figures 8 and 9 show responses in global variables to one standard deviation generalised impulses in BRIC M2 and in G3 M2, respectively. Positive innovations in the BRIC countries' liquidity lead to significant and persistent increases in global interest rates, global industrial production and commodity prices. As before, following the BRIC M2 shock, the rise in commodity prices is steep in the first few months and then continues to increase. A difference from before is that now positive innovations in BRIC M2 significantly affect global inflation. However, by comparing Figures 8 and 9, it can be seen that increases in BRIC M2 are associated with increases in global inflation that are over twice as large as those linked with increases in G3 M2.

In Figure 9 shocks to the G3 economies' liquidity are not associated with statistically significant changes in global interest rates or global industrial production. A positive innovation in G3 M2 does lead to an increase in commodity prices that is larger than in the earlier principal component model and is statistically significant for twenty months. However, positive innovations in BRIC M2 continue to be linked with a positive effect on commodity prices that is larger than is the effect of unanticipated increases in G3 liquidity on commodity (although not by as great a margin). The magnitude of this relatively larger effect of BRIC M2 compared to G3 M2 on commodity prices slowly grows over time.

\subsection{Alternative identification restrictions}

In the model restrictions implied by equation (8), commodity prices are not allowed to be affected contemporaneously by global interest rate, global industrial production, global inflation, G3 M2 and BRIC M2 in line with Kim and Roubini (2000) and Kim (2001). 
Anzuini et al. (2012) have an alternative identification setup and treat oil prices and/or commodity prices as contemporaneously endogenous. In an identification scheme in which commodity prices are contemporaneously endogenous we replace equation (8) by the following:

$$
B_{o} X_{t}=\left[\begin{array}{cccccc}
1 & -b_{01} & -b_{02} & 0 & 0 & 0 \\
-b_{10} & 1 & 0 & -b_{13} & -b_{14} & 0 \\
-b_{20} & -b_{21} & 1 & -b_{23} & -b_{24} & 0 \\
0 & 0 & 0 & 1 & -b_{34} & 0 \\
0 & 0 & 0 & 0 & 1 & 0 \\
-b_{50} & -b_{51} & -b_{52} & -b_{53} & -b_{54} & 1
\end{array}\right]\left[\begin{array}{c}
G I R_{t} \\
\Delta \log \left(G 3 M 2_{t}\right), \\
\Delta \log \left(B R I C M 2_{t}\right) \\
\Delta \log \left(G C P I_{t}\right) \\
\Delta \log \left(G I P_{t}\right), \\
\Delta \log \left(C O M_{t}\right)
\end{array}\right]
$$

It is found that the responses of the variables in the SFAVEC model in equations (6), (7) and (9) to one-standard deviation structural innovations in BRIC M2 and in G3 M2 are very similar to those shown in Figures 5 and 6. For brevity these results are not reported here and available under request.

\subsection{Alternative lag-lengths}

An alternative lag selection can be selected using the Akaike information Criterion (AIC) rather than SC criterion used in our previous estimation. The AIC select two lags (rather than one) in estimation of the SFAVEC model described in equations (6) to (8). The model is re-estimated with two lags and results are very similar to those obtained in Figures 5 and 6. While results stay statistically significant the confidence bands around point estimates tend to increase slightly (results are available under request).

\subsection{Global financial crisis}

The global financial crisis was associated with dramatic changes in commodity prices. To deal with the global financial crisis we introduce a dummy variable that takes the value 1 from July 2008 to December 2008 and 0 otherwise into equation (1). ${ }^{15}$ Results are essentially

\footnotetext{
15 Perri and Quadrini (2011) identify the third and fourth quarter of 2008 as being the global financial crises period. To correspond to this analysis we identify July 2008 to December 2008 as being the crisis period. With monthly data a narrower focus is possible. We experiment with September 2008 to November 2008 as being the global financial crises without changing results.
} 
unchanged from those in Figures 5 and 6 from following this strategy for dealing with the global financial crisis (and are available from the authors).

\section{Conclusion}

In this paper we investigate the influence of liquidity as it arises from the major developed and major developing economies on commodity and disaggregated prices. The magnitude of the positive effect of positive BRIC liquidity innovations on commodity prices compared to that of positive G3 liquidity innovations on commodity prices is much larger and the disparity grows over time. Positive shocks in BRIC liquidity have much larger effects on energy prices, mineral and metal prices, and raw material prices than do positive shocks in G3 liquidity. It is only on precious metal prices that shocks to G3 M2 have larger effects than shocks to BRIC M2. A positive shock in BRIC M2 is associated with a boom in global industrial production and global tightening in monetary policy as indicated by increases in central bank discount rates. Global industrial production and global interest rates do not respond significantly to innovations in G3 M2.

Results are robust to alternative identification schemes in the structural FAVAR, to different measurement of global variables, to treatment of the global financial crisis, and to variation in lag length. Findings suggest during what Hamilton (2013) refers as a "new industrial age" (1997-2010), characterized by billions of people making the transition from agricultural to industrial activity with increases in real income beyond subsistence levels, increases in liquidity in the major developing countries have much more powerful consequences for global commodity prices than do increase in liquidity in advanced countries. 


\section{References}

Anzuini, A., Lombardi, M.J., Pagano, P., 2012. The impact of monetary policy shocks on commodity prices. Bank of Italy Working Paper, Number 851.

Bachmeier, L.J., Swanson, N.R., 2005. Predicting Inflation: Does The Quantity Theory Help? Economic Inquiry 43, 570-585.

Barsky R.B., Kilian L., 2004. Oil and the Macroeconomy Since the 1970s. Journal of Economic Perspectives 18, 115-134.

Belke, A., Orth, W., Setzer, R., 2010. Liquidity and the dynamic pattern of asset price adjustment: A global view. Journal of Banking and Finance 34, 1933-1945.

Belke, A., Bordon, I.G., Volz, U., 2013. Effects of Global Liquidity on Commodity and Food Prices. World Development 44, 31-43.

Bernanke, B., 1986. Alternative explanations of the money-income correlation. CarnegieRochester series on Public Policy 25, 49-99.

Bernanke, B., Boivin, J., Eliasz, P.S., 2005. Measuring the Effects of Monetary Policy: A Factor-augmented Vector Autoregressive (FAVAR) Approach. Quarterly Journal of Economics 120, 387-422.

Beyer, A., Doornik, J.A., Hendry, D.F., 2000. Constructing Historical Euro-Zone Data. Economic Journal 111, 308-327.

Christiano, L.J., Eichenbaum, M., Evans, C., 1999. Monetary policy shocks: What have we learned and to what end? In: Taylor, J.B., Woodford, M. (Eds.), Handbook of Macroeconomics, Vol. 1A. North-Holland, Amsterdam, pp. 65-148.

D'Agostino, A., Surico, P., 2009. Does global liquidity help to forecast US inflation? Journal of Money, Credit and Banking 41 (2/3), 479-489.

Darius, R., Radde, S., 2010. Can Global Liquidity Forecast Asset Prices? IMF Working Paper 10/196, International Monetary Fund, Washington, D.C.

Dees, S., di Mauro, F., Pesaran, M.H., Smith, L.V., 2007, Exploring the international linkages of the euro area: a global VAR analysis. Journal of Applied Econometrics 22, 1-38.

Dungey, M., Fry-McKibbin, R., Linehan, V., 2013. Chinese Resource Demand and the Natural Resource Supplier. Working paper University of Tasmania. Forthcoming Applied Economics.

Enders, W., 2004. Applied Econometric Time Series, second ed. John Wiley and Sons, New York. 
Engle, R.F., Granger, C.W.J., 1987. Cointegration and Error-Correction: Representation, Estimation, and Testing. Econometrica 55, 251-276.

Frankel J.A., 1984. Commodity Prices and Money: Lessons from International Finance. American Journal of Agricultural Economics 66, 560-566.

Frankel J.A., Hardouvelis G.K., 1985. Commodity Prices, Money Surprises, and Fed Credibility. Journal of Money, Credit and Banking 17, 427-438.

Garratt, A., Koop, G., Mise, E., Vahey, S.P., 2009. Real-Time Prediction With UK Monetary Aggregates in the Presence of Model Uncertainty. Journal of Business \& Economic Statistics, American Statistical Association 27, 480-491.

Giese, J. V.,Tuxen, C. K., 2007. Global Liquidity, Asset Prices and Monetary Policy: Evidence from Cointegrated VAR Models. Working Paper. University of Oxford, Nuffield College and University of Copenhagen, Department of Economics

Gordon, D.B., Leeper, E.M., 1994. The Dynamic Impacts of Monetary Policy: An Exercise in Tentative Identification. Journal of Political Economy 102, 1228-47.

Hamilton, J.D., 2013. Historical Oil Shocks. In: Parker, R.E., Whaples, R.M., (Eds.), The Routledge Handbook of Major Events in Economic History. New York: Routledge Taylor and Francis Group, pp. 239-265.

Humphreys, D., 2010. The great metals boom: A retrospective. Resources Policy 35, 1-13.

Kilian, L., Hicks, B., 2013. Did Unexpectedly Strong Economic Growth Cause the Oil Price Shock of 2003-2008? Journal of Forecasting 32, 385-394.

Kim, S., 2001. International transmission of US Monetary policy shocks: evidence from VARs. Journal of Monetary Economics 48, 339-372.

Kim, S., Roubini, N., 2000. Exchange rate anomalies in the industrial countries: a solution with a structural VAR approach. Journal of Monetary Economics 45, 561-586.

Perri, F., Quadrini, V., 2011. International Recessions. National Bureau of Economic Research, NBER Working Paper 17201.

Pesaran, M. H., Y. Shin, 1998. Generalized Impulse Response Analysis in Linear Multivariate Models. Economics Letters 58, 17-29.

Radetzki, M., 2006. The anatomy of three commodity booms. Resources Policy 31, 56-64.

Ratti, R.A., Vespignani, J., 2013. Why are crude oil prices high when global activity is weak? Economics Letters 121, 133-136.

Roberts, I., Rush, A., 2010. Sources of Chinese demand for resource commodities. Research Discussion Paper 2010-8, Reserve Bank of Australia. 
Sims, C.A., 1980. Macroeconomics and Reality. Econometrica 48, 1-48.

Sims, C.A., Zha, T., 1995. Does monetary policy generate recessions?: Using less aggregate price data to identify monetary policy. Working paper, Yale University, CT.

Sims, C.A., Zha, T., 2006. Does Monetary Policy Generate Recessions?, Macroeconomic Dynamics 10, 231-272.

Stock, J.H., Watson, M.W., 2002. Forecasting using principal components from a large number of predictors. Journal of the American Statistical Association 97, 1167-1179.

Sousa, J., Zaghini, A., 2007. Global Monetary Policy Shocks in the G5: A SVAR Approach. Journal of International Financial Markets, Institutions and Money 17, 403-419.

Swanson, N.R., 1998. Money and output viewed through a rolling window. Journal of Monetary Economics 41, 455-474. 
Table 1: Correlation between country-specific and global factors

\begin{tabular}{lccc}
\hline Country/Global & Global/Country IR & Global/Country IP & Global/Country CPI \\
\hline Euro area & 0.84 & 0.61 & 0.99 \\
US & 0.89 & 0.62 & 0.99 \\
China & 0.62 & 0.93 & 0.95 \\
Japan & 0.51 & 0.31 & -0.75 \\
UK & 0.89 & -0.62 & 0.97 \\
India & 0.32 & 0.92 & 0.95 \\
Russia & 0.68 & 0.99 & 0.99 \\
Brazil & 0.38 & 0.97 & 0.99 \\
\hline
\end{tabular}

Notes: Correlations between country-specific and global factor for the short-term interest rate (IR), for industrial production (IP), and for the inflation rate (CPI) are reported in the columns in Table 1. The global factors are given by first principal components for the global interest rate $(G I R)$, global industrial production rate $(G I P)$, and global inflation rate $(G C P I)$.

Table 2: Granger causality tests 1999:1-2012:12 (log-level).

Null Hypothesis: $x$ does not Granger cause y

\begin{tabular}{lcccc}
\hline \multicolumn{1}{c}{ Granger test/Lags } & 1 & 3 & 6 & 12 \\
Commodity price does not Granger cause BRIC M2 & 0.15 & 0.35 & 0.71 & 1.47 \\
BRIC M2 does not Granger cause commodity prices & $3.08^{* * *}$ & $8.05^{* * *}$ & $4.71^{* * *}$ & $3.15^{* * *}$ \\
& & & & 1.53 \\
Commodity price does not Granger cause G3 M2 & 0.22 & 0.26 & 1.16 \\
G3 M2 does not Granger c causeommodity prices & $6.37^{* * *}$ & $4.52^{* * *}$ & $2.39^{* * *}$ & $2.29^{* * *}$ \\
\hline
\end{tabular}

Notes: Variables are in logs. ${ }^{* * *}$ Indicates rejection of the null hypothesis at $1 \%$ level of significance.

Table 3: Granger causality tests 1999:1-2012:12 (log-first difference).

Null Hypothesis: $\mathrm{x}$ does not Granger cause $\mathrm{y}$

\begin{tabular}{lcccc}
\hline \multicolumn{1}{c}{ Granger test/Lags } & 1 & 3 & 6 & 12 \\
Commodity price does not Granger cause BRIC M2 & 0.20 & 1.76 & $2.22^{* * *}$ & 1.51 \\
BRIC M2 does not Granger cause commodity prices & $7.04 * * *$ & $4.77^{* * *}$ & $2.32^{* * *}$ & $2.27^{* * *}$ \\
Commodity prices does not Granger cause G3 M2 & 0.24 & $2.28^{* * *}$ & 1.34 & 0.96 \\
G3 M2 does not Granger cause commodity prices & 1.17 & 1.49 & 1.28 & 1.41 \\
\hline
\end{tabular}

Notes: Variables are in log-first differences. ${ }^{* * *}$ Indicates rejection of the null hypothesis at $1 \%$ level of significance. 
Table 4: Test for unit roots 1999:1-2012:12:

\begin{tabular}{|c|c|c|c|c|c|}
\hline \multicolumn{6}{|c|}{ variables } \\
\hline Level & $\mathrm{ADF}$ & KPSS & First difference & $\mathrm{ADF}$ & KPSS \\
\hline $\log \left(G 3 M 2_{t}\right)$ & -0.13 & $1.61 * * *$ & $\Delta \log \left(G 3 M 2_{t}\right)$ & $-12.4 * * *$ & 0.09 \\
\hline $\log \left(B R I C M 2_{t}\right)$ & 2.20 & $1.62 * * *$ & $\Delta \log \left(B R I C M 2_{t}\right)$ & $2.6 *$ & 0.73 \\
\hline $\log \left(\mathrm{GCPI}_{t}\right)$ & 0.47 & $1.62 * * *$ & $\Delta \log \left(\mathrm{GCPI}_{t}\right)$ & $-8.31 * * *$ & 0.13 \\
\hline $\log \left(\mathrm{GIP}_{t}\right)$ & -1.48 & $1.48 * * *$ & $\Delta \log \left(\mathrm{GIP}_{t}\right)$ & $-5.93 * * *$ & 0.08 \\
\hline $\log \left(\right.$ Commodities $\left._{t}\right)$ & -1.52 & $1.53 * * *$ & $\Delta \log \left(\right.$ Commodities $\left._{t}\right)$ & $-8.86 * * *$ & 0.04 \\
\hline $\log \left(\right.$ Energy $\left.y_{t}\right)$ & -2.20 & $1.52 * * *$ & $\Delta \log \left(\right.$ Energy $\left._{t}\right)$ & $-9.70 * * *$ & 0.07 \\
\hline $\log \left(\right.$ Agricultural $\left._{t}\right)$ & -0.66 & $1.52 * * *$ & $\Delta \log \left(\right.$ Agricultural $\left._{t}\right)$ & $-8.16 * * *$ & 0.11 \\
\hline $\log \left(\right.$ Food $\left._{t}\right)$ & -0.77 & $1.53 * * *$ & $\Delta \log \left(\right.$ Food $\left._{t}\right)$ & $-8.26 * * *$ & 0.10 \\
\hline $\log \left(\right.$ Min. and metal $\left._{t}\right)$ & -1.31 & $1.39 * * *$ & $\Delta \log \left({\left.\text { Min. and } \text { metal }_{t}\right)}\right.$ & $-8.13 * * *$ & 0.07 \\
\hline $\log \left(\right.$ Precious met. $\left._{t}\right)$ & 0.50 & $1.58 * * *$ & $\Delta \log \left(\right.$ Precious metal $_{t}$ & $-11.8 * * *$ & 0.21 \\
\hline $\log \left(\right.$ Raw material $\left._{\cdot t}\right)$ & -1.00 & $1.45 * * *$ & $\Delta \log \left(\right.$ Raw material $\left._{t}\right)$ & $-5.98 * * *$ & 0.07 \\
\hline
\end{tabular}

Notes: The null hypothesis for the ADF test is the variable has a unit root and the null hypothesis for the KPSS test is the variable is stationary. The first difference of the series is indicated by $\Delta$. The lag selection criteria for the ADF is based on Schwarz information Criteria (SIC) and for the KPSS is the Newey-West Bandwidth. ***, **, * indicates rejection of the null hypothesis at $1 \%, 5 \%$ and $10 \%$, levels of significance.

Table 5: VAR Johansen cointegration test summary:

5.1 Cointegration test: $\operatorname{logs}$ of commodity prices and money (G3 and BRIC)

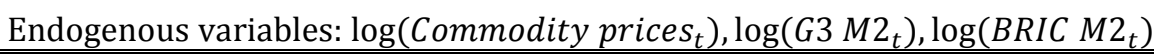

Exogenous variables: $\log \left(\right.$ Global industrial production $\left._{t}\right)$, Global interest rate

Data Trend:
Test Type
Trace
Max-Eig

None
Intercept
1
1

Linear

Intercept

0

0

5.2 Cointegration test: logs of global inflation (GCPI), money (G3 M2 and BRIC M2) and global output (GIP).

Endogenous variables: $\log \left(\right.$ Commodity $\left._{\text {prices }}\right), \log \left(\right.$ Global Money $\left._{t}\right)$

Exogenous variables: $\log \left(\right.$ Global industrial production $\left.{ }_{t}\right)$, Global interest rate

\begin{tabular}{ccc} 
Data Trend: & None & Linear \\
Test Type & Intercept & Intercept \\
Trace & 2 & 1 \\
Max-Eig & 2 & 1 \\
\hline
\end{tabular}

Notes: *Critical values based on MacKinnon-Haug-Michelis (1999). **Selected (0.05 level*) Number of Cointegrating Relations by Model 
Figure 1: BRIC M2 and G3 M2 in billions of US dollars: 1999:01-2012:12

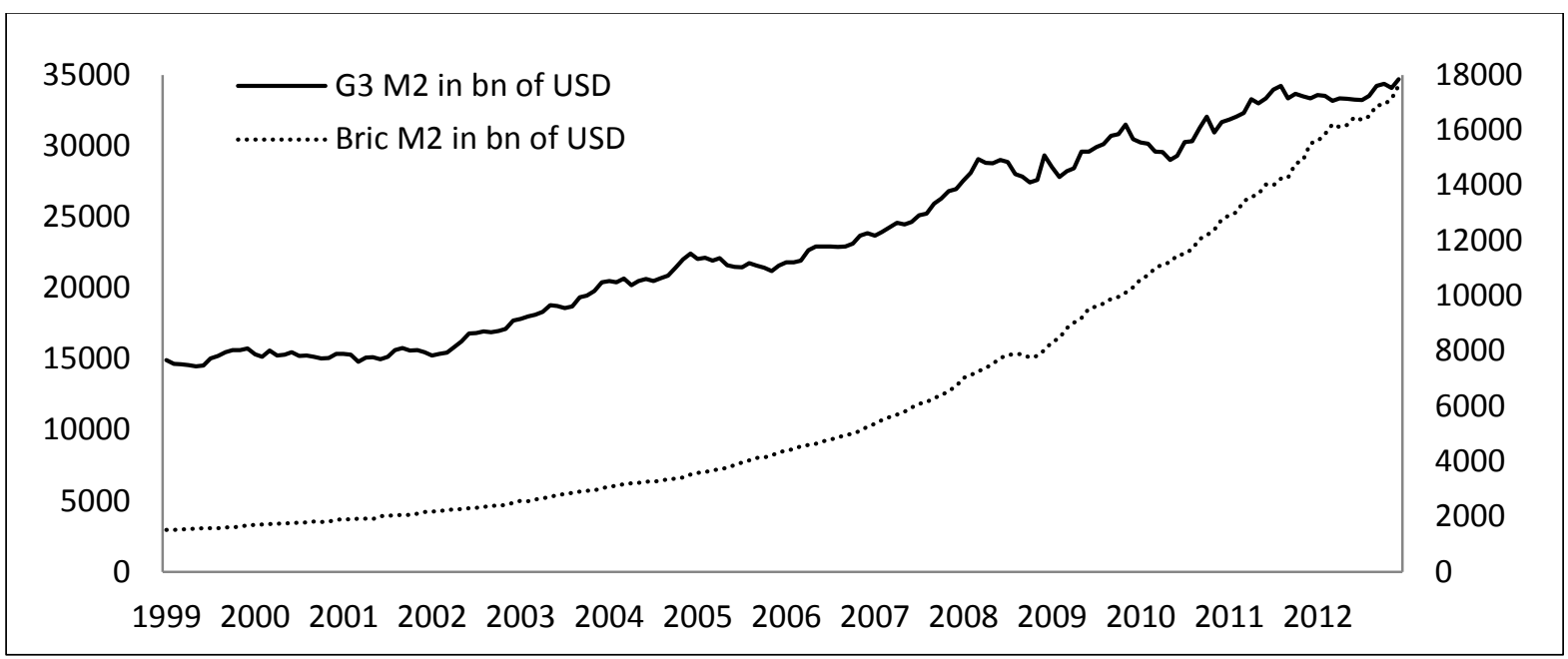

Notes: The BRIC countries are Brazil, Russia, India and China. G3 economies are the US, EU and Japan. Data are monthly over 1999:01-2012:12 in billions of US dollars. The scale of the right hand side of Figure 1 is for M2 for the BRIC countries and the scale of the left hand side of Figure 1 is for M2 for the G3.

Figure 2: Log of US dollar commodity price indices: 1999:01-2012:12

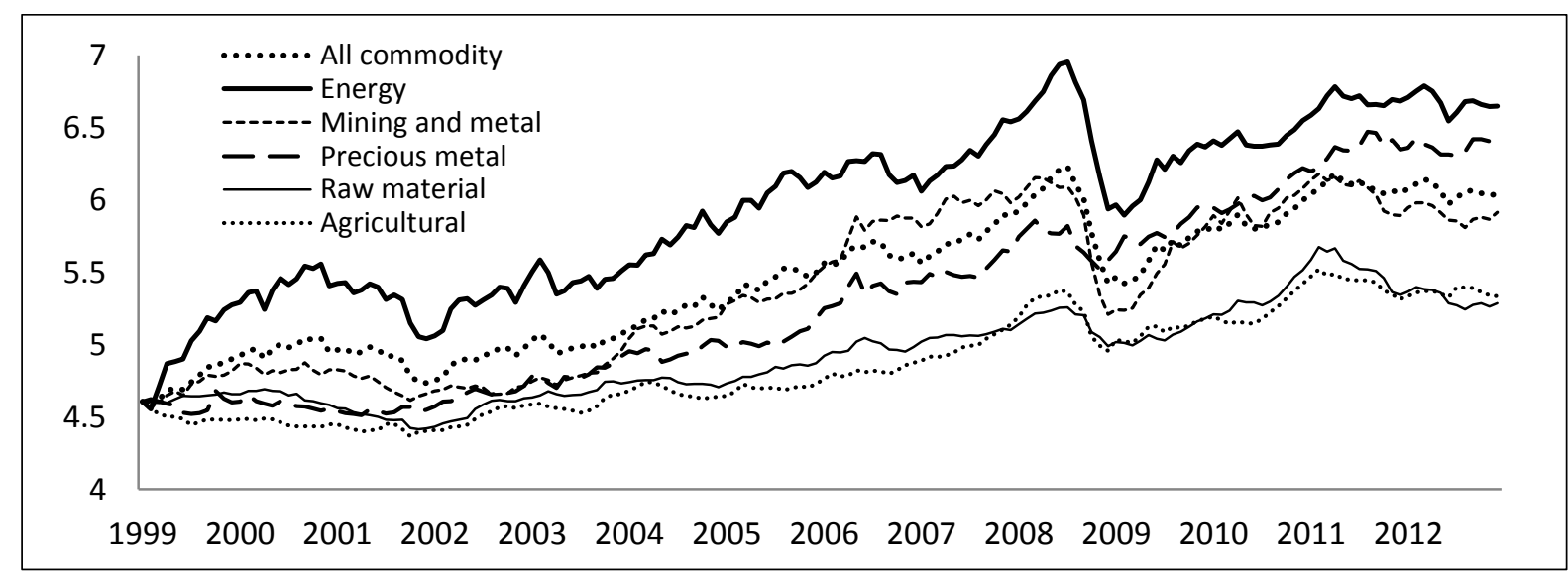

Notes: The US dollar commodity price component indices are for energy commodities, agriculture commodities, mineral and metal commodities, precious metal commodities, and raw materials commodities. 
Figure 3a: Principal components estimation of global interest rate: 1999:01 to 2012:12

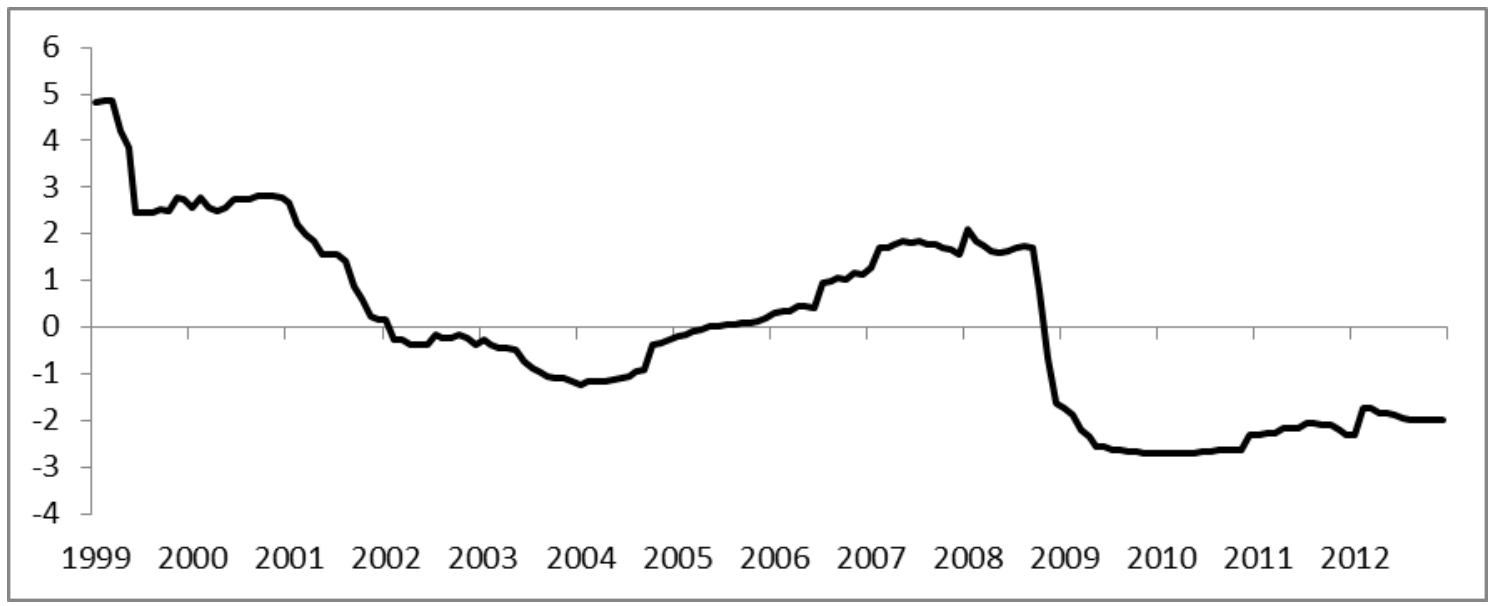

Figure 3b: Principal components estimation of global inflation: 1999:01 to 2012:12

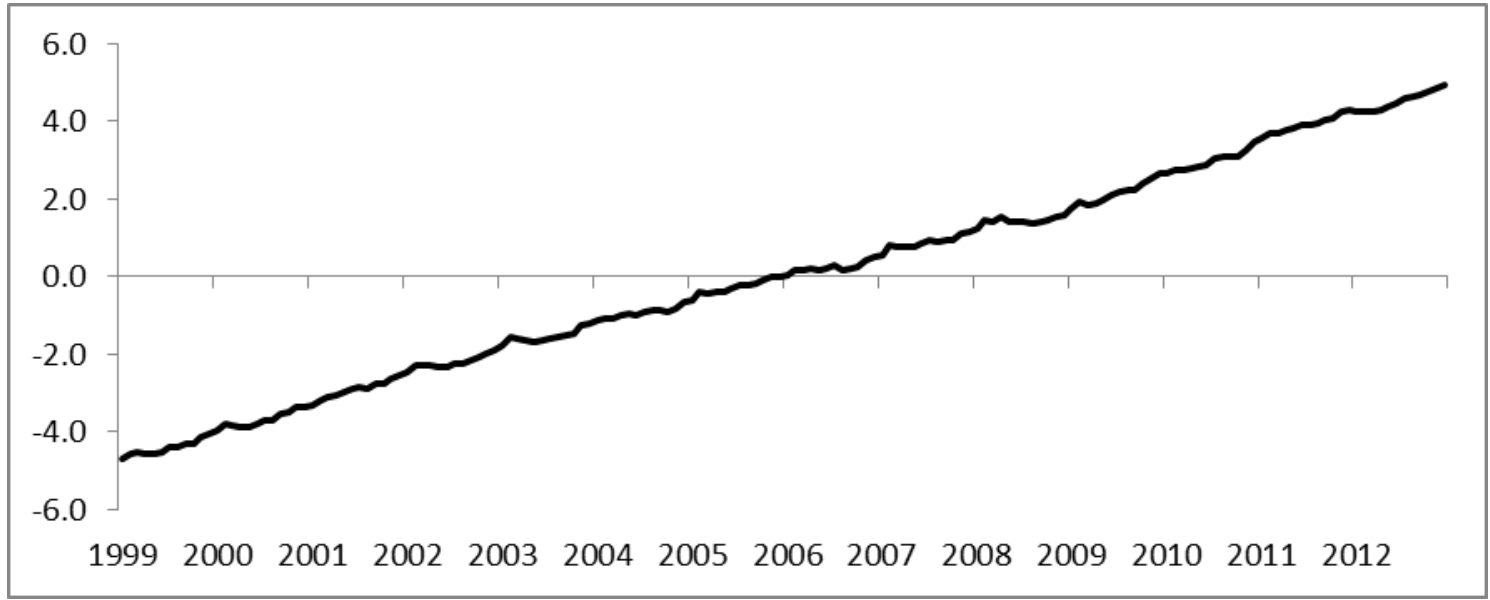

Figure 3c: Principal components estimation of global real output: 1999:01 to 2012:12

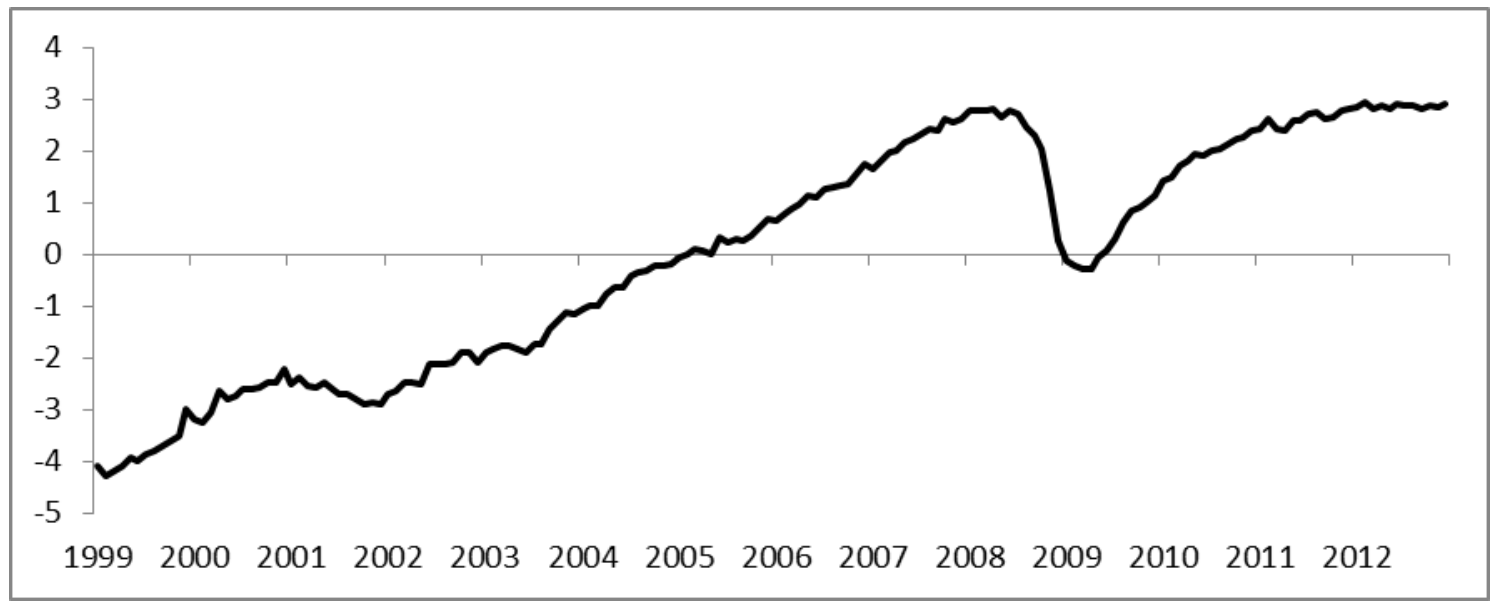

Notes: The principal components of the BRIC and G3 economies' short-term interest rate, industrial production, and inflation are taken to represent global interest rate, global industrial production, and global inflation, respectively. 
Figure 4: One standard deviation generalised impulse response functions of global variables to shocks in BRIC M2
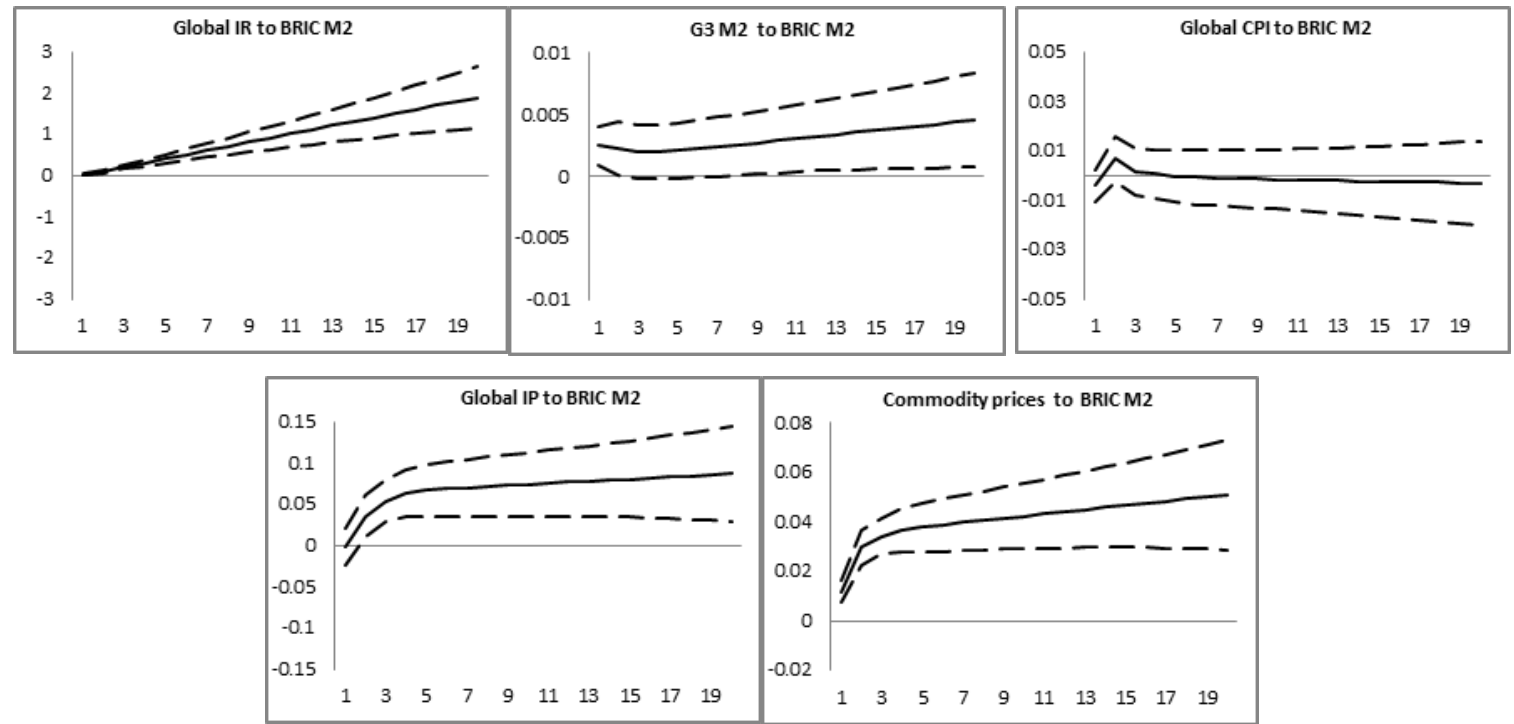

Notes: The one standard deviation generalised impulse response functions of the global interest rate (Global IR), G3 M2, global CPI (Global CPI), global industrial production (Global IP), global commodity price (Commodity prices) to structural innovations in BRIC M2, based on the SFAVEC model in equations (6)-(8). The global variables are based on principal components.

Figure 5. One standard deviation generalised impulse response functions of global variables to shocks in G3 M2.
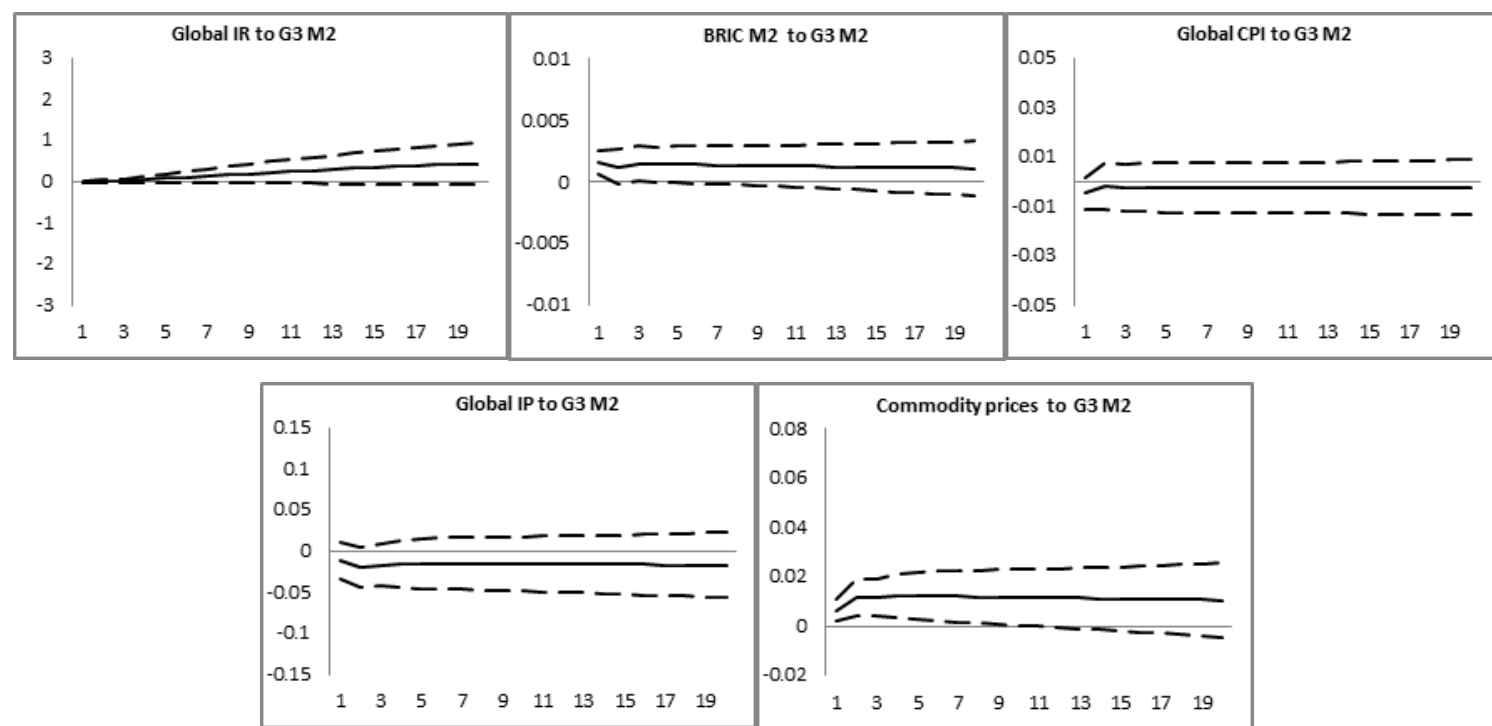

Notes: The one standard deviation generalised impulse response functions of the global interest rate (Global IR), BRIC M2, global CPI (Global CPI), global industrial production (Global IP), global commodity price (Commodity prices) to structural innovations in G3 M2, based on the SFAVEC model in equations (6)-(8). The global variables are based on principal components. 
Figure 6a: Cumulative effect of structural shocks to BRIC M2 and to G3 M2 on commodity price

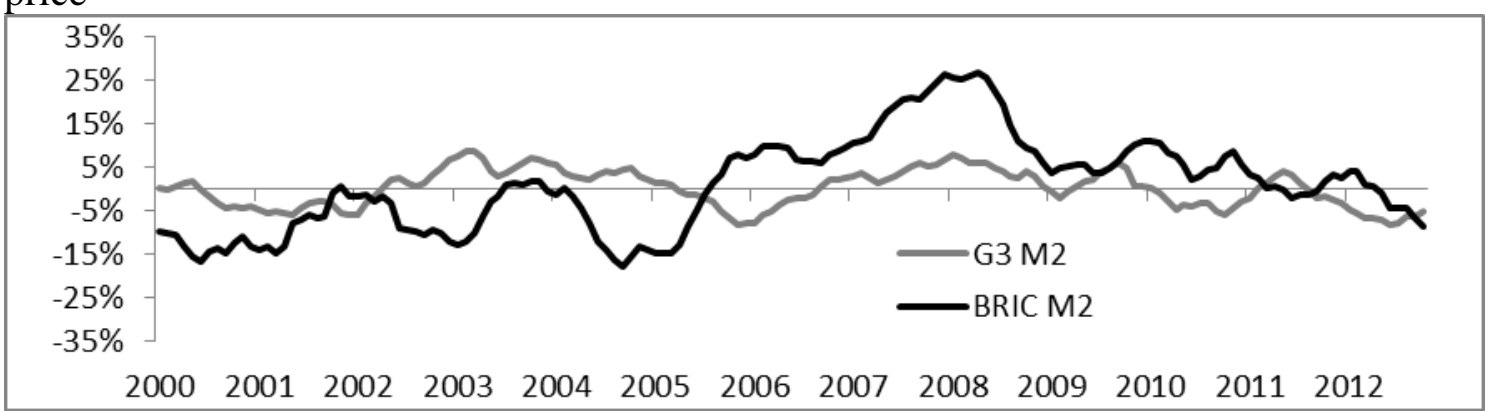

Notes: The cumulative contributions to commodity price of the structural shocks to G3 M2 and to BRIC M2 are obtained from estimating the SFAVEC model in equations (6)-(8). The cumulative contributions of structural shocks to commodity price are the moving average of the last 12 months expressed at an annualized rate.

Figure 6b: Difference in cumulative effect on commodity price of structural shocks to BRIC M2 and G3 M2

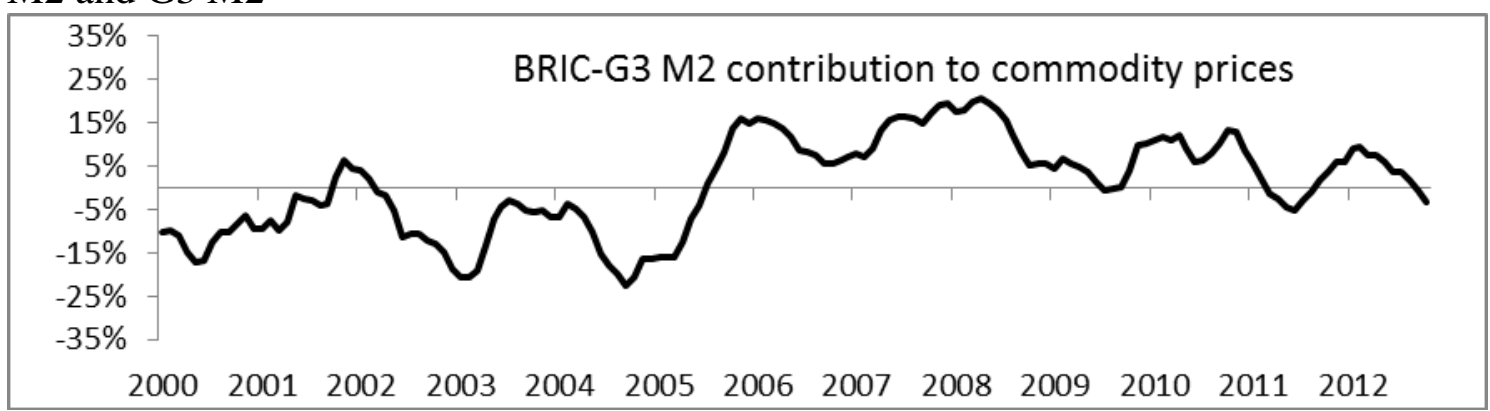

Notes: A positive (negative) value for difference in cumulative effect of structural shocks to BRIC M2 and G3M2 on commodity price, BRIC-G3 M2, indicates larger (smaller) effect of BRICM2 on commodity price than that of G3M2. 
Figure 7: One standard deviation generalised impulse response functions of disaggregated commodity prices to shocks in G3 M2 and BRIC M2.

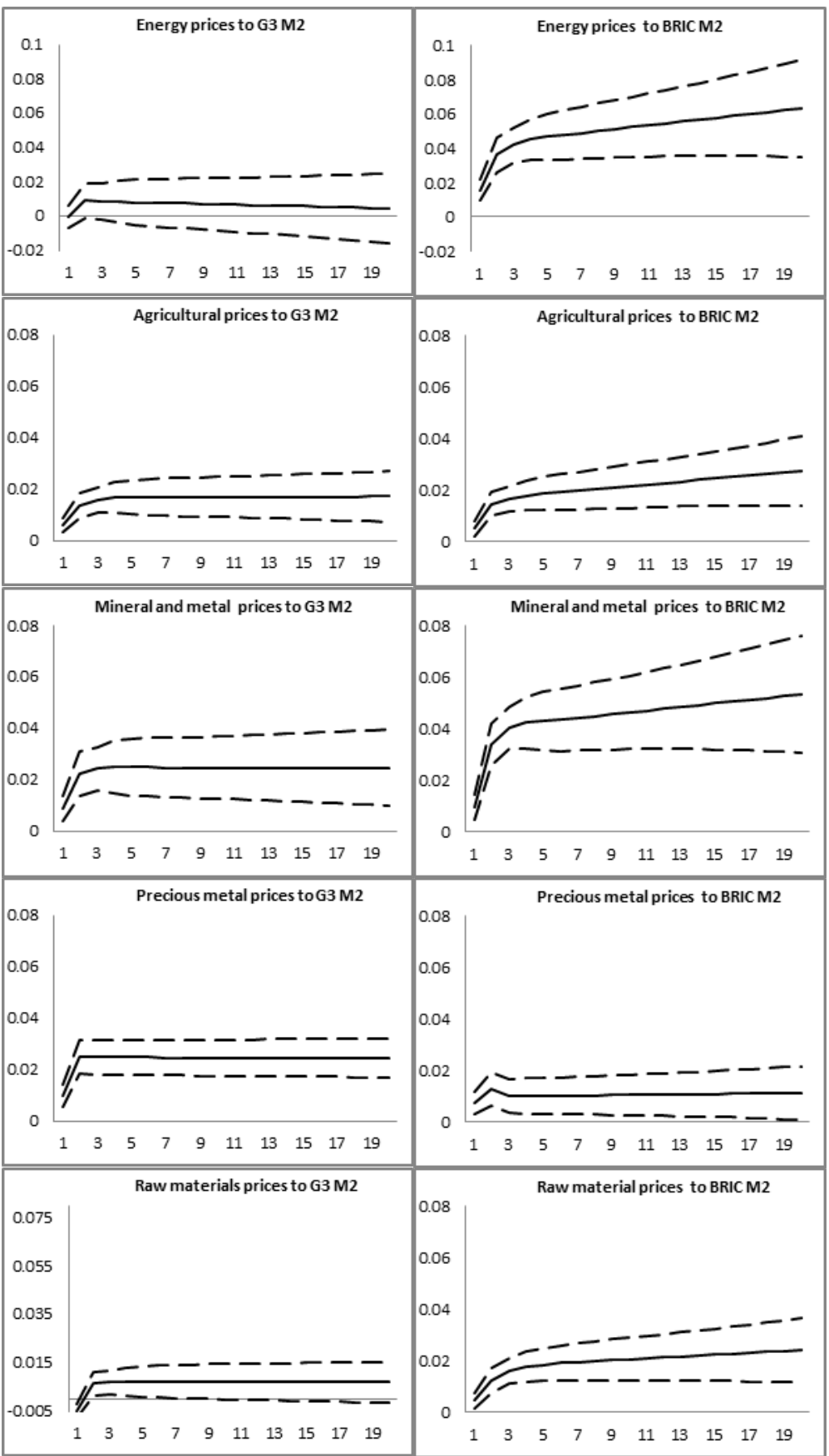

Notes: The one standard deviation generalised impulse response functions of the commodity price component indices to structural innovations in G3 M2 and in BRIC M2 are shown in first column and in the second column, respectively, based on the SFAVEC model in equations (6)-(8). The commodity price component indices considered are energy commodities, agriculture commodities, mineral and metal commodities, precious metal commodities, and raw materials commodities. 
Figure 8: One standard deviation generalised impulse response functions of global variables to shocks to BRIC M2 (Global variables weighted by nominal GDP).
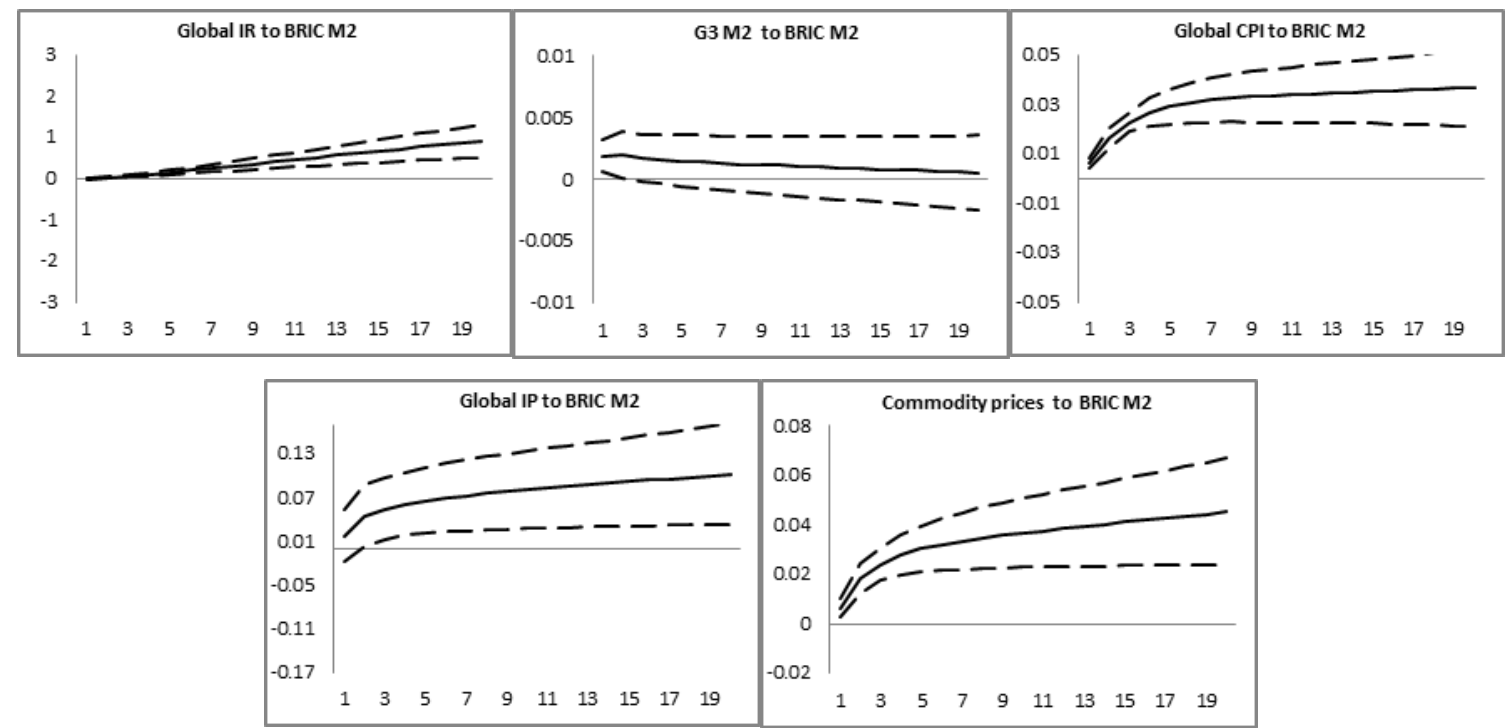

Notes: The one standard deviation generalised impulse response functions of the global interest rate (Global IR), G3 M2, global CPI (Global CPI), global industrial production (Global IP), global commodity price (Commodity prices) to structural innovations in BRIC M2, based on the SVEC model in equations (6)-(8) with global variables constructed by summing national variables weighted by relative nominal GDP.

Figure 9: One standard deviation generalised impulse response functions of global variables to shocks to G3 M2 (Global variables weighted by nominal GDP).
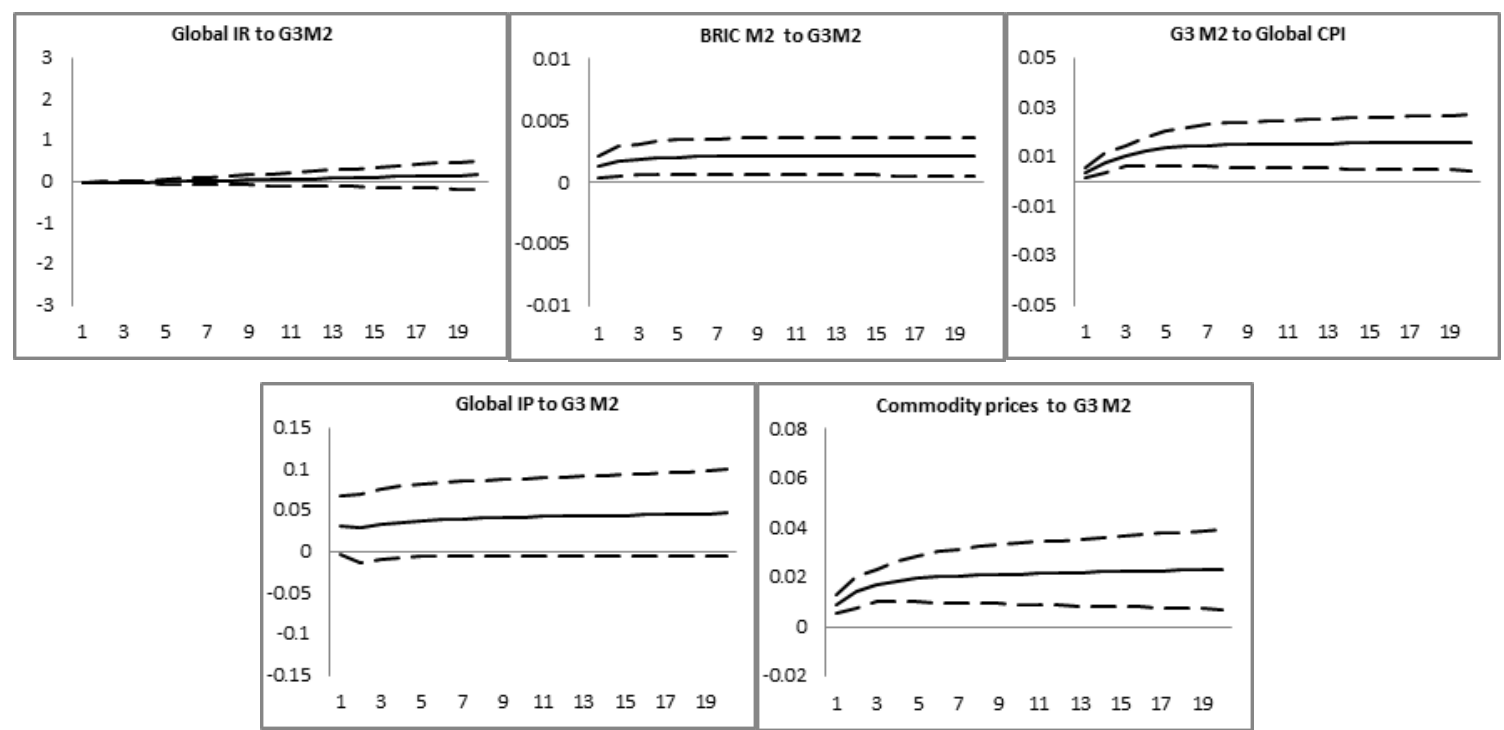

Notes: The one standard deviation generalised impulse response functions of the global interest rate (Global IR), BRIC M2, global CPI (Global CPI), global industrial production (Global IP), global commodity price (Commodity prices) to structural innovations in G3 M2, based on the SVEC model in equations (6)-(8) with global variables constructed by summing national variables weighted by relative nominal GDP. 


\section{Appendix A: The FAVAR model}

This Appendix briefly describes the use of principal component estimation in conjunction with a VAR model. Let $X_{t}$ denote a $N x 1$ vector of time series variables, $Y_{t}$ a vector $M \times 1$ observable time series variables that constitute a subset of $X_{t}$ and $F_{t}$ a $k x 1$ vector of unobserved factors that capture most of the information contained in $X_{t}$. Bernanke et al. (2005) describe the joint dynamic of $\left(F_{t}, Y_{t}\right)$ as follows:

$$
\left[\begin{array}{l}
F_{t} \\
Y_{t}
\end{array}\right]=\Phi *(L)\left[\begin{array}{l}
F_{t-1} \\
Y_{t-1}
\end{array}\right]+v_{t} \leftrightarrow \Phi(L)\left[\begin{array}{l}
F_{t} \\
Y_{t}
\end{array}\right]=v_{t}
$$

where $\Phi(\mathrm{L})=\mathrm{I}-\Phi *(\mathrm{~L}) \mathrm{L}=\mathrm{I}-\Phi_{1} L-\cdots-\Phi_{d} L^{d}$ is a lag polynomial of finite order $\mathrm{d}$ in the lag operator $\mathrm{L}, \Phi_{j}(j=1, \ldots, d)$ is the coefficient matrix and $v_{t}$ is an error term with zero mean and covariance matrix Q. Equation (10) is VAR model, which includes both observable and unobservable variables. We can assume that the relation between the 'informal' time series $X_{t}$, the observed variables $Y_{t}$ and the factor $F_{t}$ can be summarised in the following representation of a dynamic factor model:

$$
X_{t}=\Lambda^{f} F_{t}+\Lambda^{y} Y_{t}+e_{t}
$$

Where $\Lambda^{f}$ is a N x k matrix of factor loadings, $\Lambda^{y}$ is $\mathrm{Nx} \mathrm{M}$ and $e_{t}$ is the vector of $\mathrm{N} \mathrm{x} 1$ error cross-sectionally and correlated and with mean zero. Following Stock and Watson (2002) $X_{t}$ does not depend on the lagged values of $F_{t}$. Since we assume that $\mathrm{M}+\mathrm{k} \ll \mathrm{N}$, the amount of information that can be handled in the FAVAR increases significantly in comparison to standard VAR model. 
Appendix B: One standard deviation generalised impulse response functions

The one standard deviation generalised impulse response functions of the variables in the SFAVEC model in equations (6)-(8) to shocks to all the variables are reported in Table 10.

Figure 10: One standard deviation generalised impulse response functions
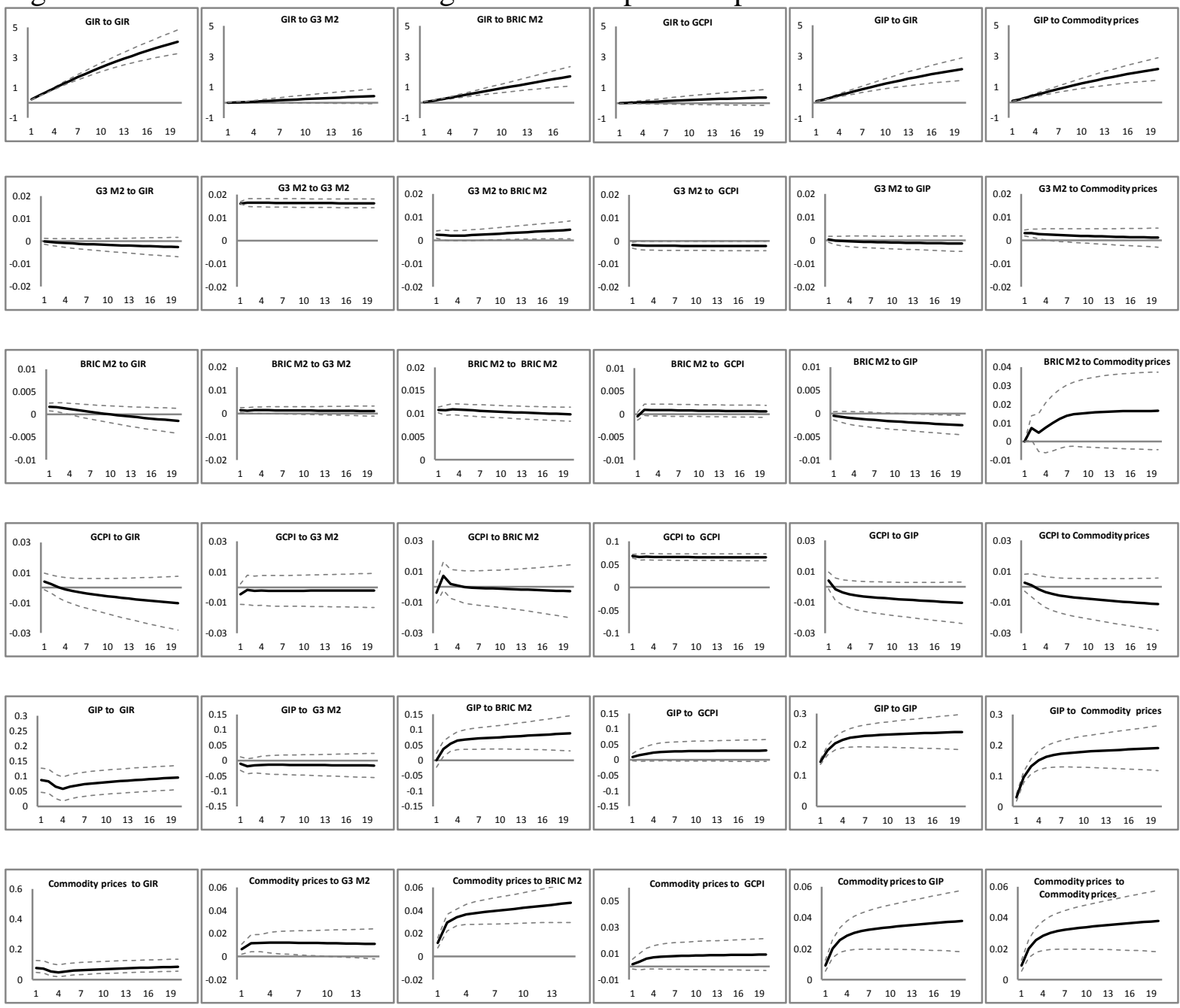

Notes: The one standard deviation generalised impulse response functions of the global interest rate (Global IR), G3 M2, BRIC M2, global CPI (Global CPI), global industrial production (Global IP), global commodity price (Commodity prices) to structural innovations in all the endogenous variables in the SFAVEC model in equations (6)-(8). The global variables are based on principal components. 


\section{School of Economics and Finance Discussion Papers}

2013-08

2013-07

2013-06

2013-05

2013-04

2013-03

2013-02

2013-01

2012-11

2012-10

2012-09

2012-08

2012-07

2012-06

2012-05

2012-04

2012-03

2012-02

2012-01

2011-06

Commodity Prices and BRIC and G3 Liquidity: A SFAVEC Approach, Ronald A Ratti and Joaquin L Vespignani

Chinese Resource Demand and the Natural Resource Supplier Mardi Dungy, Renée Fry-McKibbin and Verity Linehan

Not All International Monetary Shocks are Alike for the Japanese Economy, Joaquin L Vespignani and Ronald A Ratti

On Bootstrap Validity for Specification Tests with Weak Instruments, Firmin Doko Tchatoka

Chinese Monetary Expansion and the US Economy, Joaquin L Vespignani and Ronald A Ratti

International Monetary Transmission to the Euro Area: Evidence from the US, Japan and China, Joaquin L Vespignani and Ronald A Ratti

The impact of jumps and thin trading on realized hedge ratios? Mardi Dungey, Olan T. Henry, Lyudmyla Hvozdyk

Why crude oil prices are high when global activity is weak?, Ronald A Rattia and Joaquin L Vespignani

Crude Oil Prices and Liquidity, the BRIC and G3 Countries, Ronald A Ratti and Joaquin L Vespignani

Crude Oil Prices: China’s Influence Over 1996-2011, Ronald A Ratti and Joaquin L Vespignani

Exchange Rate Risk Exposure and the Value of European Firms, Fabio Parlapiano and Vitali Alexeev

Ranking Systemically Important Financial Institutions, Mardi Dungey, Matteo Luciani and David Veredas

Identification-Robust Inference for Endogeneity Parameters in Linear Structural Models, Firmin Doko Tchatoka and Jean-Marie Dufour

Specification Tests with Weak and Invalid Instruments, Firmin Doko Tchatoka

Liquidity and Crude Oil Prices: China’s Influence Over 1996-2011, Ronald A. Rattia and Joaquin L. Vespignani

On the Validity of Durbin-Wu-Hausman Tests for Assessing Partial Exogeneity Hypotheses with Possibly Weak Instruments, Firmin Doko Tchatoka

Endogenous Crisis Dating and Contagion Using Smooth Transition Structural GARCH, Mardi Dungey, George Milunovich, Susan Thorp and Minxian Yang

Testing for Partial Exogeneity with Weak Identification, Firmin Doko Tchatoka

On the Correspondence Between Data Revision and Trend-Cycle Decomposition, Mardi Dungey, Jan PAM Jacobs and Jian Tian

Systematic and Liquidity Risk in Subprime-Mortgage Backed Securities, Mardi Dungey, Gerald P. Dwyer and Thomas Flavin

Copies of the above mentioned papers and a list of previous years' papers are available from our home site at http://www.utas.edu.au/economics-finance/research/ 